\title{
Imbalanced Sex Ratio in Haryana: Rural and Urban Dimensions
}

\author{
Kavita $^{1}$ and Ved Parkash ${ }^{2 *}$ \\ ${ }^{1}$ Department of Political Science, M.D. University, Rohtak, Haryana, India \\ ${ }^{2}$ Department of Political Science, Govt. College, Chhara, Jhajjar, Haryana, India \\ *Corresponding author: vedvats7@gmail.com
}

\begin{abstract}
Haryana has the most severe shortage of girls compared to boys and stand bottom among all states of India. The discrimination against girl's child and strong son preference over daughters is well known in Indian society which is largely responsible for resulting decisive sex ratio. The issue of gender unfairness with the girl from womb to real-world compel to think that despite the mounting modernization and societal development why this significant segment of society is treated with double standards. The present study is coupled with the state Haryana which is recognized not only for its economic development but also far behind in sexual characteristics. The main motive of the work is to analyse the regional variations in sex ratio in Haryana during different time periods. There is no doubt that the state has questioning distinction of having the worst male-female ratio which is really an unprofessed adversity having its cavernous and horrifying impacts upon society in future. Several reasons are ascribed to the deteriorating numeral of females in proportion to males. It is very surprising that slaughter of girl child both before and after birth is still experienced in the state in spite of legal prevention and many policies and programmes that support girls like 'Beti Bachao Beti Padao', 'Haryana Kanya Kosh', 'Apki Beti Hamari Beti' etc. It has been found that male-female ratio in the state is imbalanced and continuously going to decline from 1981 to 2011 except a little improvement and both urban and rural areas are facing severe scarceness of females over males.
\end{abstract}

Keywords: Sex Composition, Unfairness, Decisive Sex Ratio and Scarceness

The precise term 'Sex' may be described as an anatomical and psychological characteristic which symbolize the biological 'maleness' and 'femaleness (Stoller, 1968). In geographical studies, the sex composition is expressed in terms of a ratio between the numerical strength of males and females in the total population. The possible balance in number of men and women is an ideal condition of the population (Singh, 2010). As sex ratio is both cause and consequence of a number of demographic attributes (fertility, mortality, marital status, life expectancy and migration). The different types of sex composition, primary (at the time of conception), secondary (at the time birth) and tertiary (at the time enumeration) are influenced at different levels by various population phenomenon (age of mother, determination of sex and abortion, female infanticide, status of women) as well as assortment of other external factors. Interestingly, even nature appears with differences male and female population size that is not any issue of worry but when these differences convert into inequality owing to relevance of socially and ethnically assembled surroundings and chronological conditions, then it turn into matter of great concern for every discipline. This drastic dissimilarity in both sexes leads to adverse demographic and social impacts (NIPCCD, 2008). As the two sexes play partly contrasting and corresponding roles in economy and society, the study of sex composition presume additional importance for population geographers (Chandna, 1996).

Despite being one of leading economies of the world, India is still burdened with dilapidated sex 
ratio in both, child as well as adult population. The UN organization in its report titled 'Sex Ratios and Gender Biased Sex Selection: History, Debates and Future Directions' has also noticed this crisis and warned that there is need of pressing deeds to assuage the moribund sex ratio which has already reached at the level of emergency proportions (Dawn and Basu, 2015). In India with growing prosperity the tendency of having small family mainly in urban areas is continuously raising in new emerging society. The preference of lesser number of children especially male as a security of their old age educated parents are more associated with determining ante natal sexual category (Atkins, 1997, Brogen et al. 2009, and Kalantry, 2013). It has been observed that new medical technology is widely used for illegal abortion rather than to assess the health status of foetus (Arnold et al. 2002) which supports the fact that sometimes the advancement of any technology can be a double edged sword (Sharma, Kumar and Kavita, 2018; Shetty \& Shetty, 2014). Surprisingly but truly census of India 2011, found that there are many shocking incidences of atrocious killings (by poisoning, drawing, dumping in garbage, starvation) of female children after birth with active participation of females members in some rural areas of the country (Majumdar, 2014). The household level certain domestic norms primed by society lead to give healthier care to sons than daughters. This fact of giving a petite worth to girls adds to under nutrition and unintentional results of excess female mortality and morbidity (Dasgupta, 1987).

Whereas the matter of Haryana, Census of India has listed it as gender critical state having lowest sex ratio in the country with number of 879 female per 1000 male which shows that unfortunately the prevalence patriarchal position and strong son preference over daughters is still dominating the society (Edmeades et al. 2011 and Jatrana, 2003) where male is considered as an asset and female as a liability. A piece of writing exposes the bitter truth that in Haryana with spending lot of fares and travelling far distance, getting a woman is much easier than a well-bred buffalo (Chhabra, 2011; Sharma et al. 2018). So it is really requisite to mitigate this disquieting deficiency of females because it is clear that no nation, society or commune can assert to be the part of civilized world and affirm cranium height with condoning the practice of prejudice against one significant half of the community.

\section{Objectives}

The study of sex composition has vital significance to understand the population structure and its eccentricity within any territorial area. Keeping in the view, the present work intends to find out the following objective:

- To analyse the trends in sex ratio in India and Haryana from 1901-2011.

- To examine the spatial and temporal variations in sex ratio in Haryana with rural and urban areas and to find out the causes behind those fluctuations.

\section{MATERIALS AND METHODS}

The paper is based on secondary data which have been assembled from Directorate of the Census Operations, Haryana composed under the enumeration of Census of India conducted from 1981 to 2011.

\section{Study Area}

The state of Haryana is located in North-western part of India having a geographical extension of $27^{\circ} 40^{\prime}$ to $29^{\circ} 42^{\prime}$ North latitudes and $74^{\circ} 54^{\prime}$ to $77^{\circ}$ $40^{\prime}$ East longitudes. It came into existence on 1 st of November 1966. It covers an area of 44,212 square kilometres which comprises the 1.34 percent of total area of the country (Sharma and Kumar, 2018).

\section{RESULTS AND DISCUSSION}

\section{Trends of Sex Ratio in India and Haryana}

The statics show the overall and rural-urban differentiation in sex ratio in India and Haryana. In 1901, the census statics put the figure at 972, 979 and 910 female per 1000 males in total, rural and urban areas respectively whereas in Haryana this numeral was 867,861 and 908 females. The successive census also recorded the fall in sex ratio with increasing difference in rural and urban areas. In 1951, the overall sex ratio of India was 946 females per 1000 males with a great decline of 26 females in total as compared to 1901 whereas it was 965 and 860 in rural and urban area in that order. In the same time, the state had registered the 871 females per 
Table 1: Rural-Urban Sex Ratio of India and Haryana, 1901-2011

\begin{tabular}{ccccccccc}
\hline \multirow{2}{*}{ Census Year } & \multicolumn{9}{c}{ India } & \multicolumn{4}{c}{ Haryana } \\
\cline { 2 - 8 } & Total & Rural & Urban & $\begin{array}{c}\text { Rural-Urban } \\
\text { Differential }\end{array}$ & Total & Rural & Urban & $\begin{array}{c}\text { Rural-Urban } \\
\text { Differential }\end{array}$ \\
\hline 1901 & 972 & 979 & 910 & 69 & 867 & 861 & 908 & -47 \\
1911 & 964 & 975 & 872 & 103 & 835 & 834 & 842 & -8 \\
1921 & 955 & 970 & 846 & 124 & 844 & 848 & 811 & 37 \\
1931 & 950 & 966 & 838 & 128 & 844 & 851 & 792 & 59 \\
1941 & 945 & 965 & 831 & 134 & 869 & 879 & 806 & 73 \\
1951 & 946 & 965 & 860 & 105 & 871 & 877 & 845 & 32 \\
1961 & 941 & 963 & 845 & 118 & 868 & 874 & 842 & 32 \\
1971 & 930 & 949 & 858 & 91 & 867 & 870 & 853 & 17 \\
1981 & 935 & 952 & 880 & 72 & 870 & 876 & 849 & 27 \\
1991 & 927 & 939 & 894 & 45 & 865 & 864 & 868 & -4 \\
2001 & 933 & 946 & 900 & 46 & 861 & 866 & 847 & 19 \\
2011 & 940 & 947 & 926 & 21 & 879 & 882 & 873 & 9 \\
\hline
\end{tabular}

Source: Primary Census Abstract, Haryana 2011.

1000 males in overall, 877 number of female in rural and 845 in urban areas. In India, the female male ratio was 935 in total, 952 in rural and 880 per 1000 males in urban areas in 1981 while these figures were 870,876 and 849 females in context to Haryana state in same time.

The enumeration of census 2011 showed minor improvement in number of females per thousand males in all categories of India and Haryana. It has been recorded in 2011; overall sex ratio of India is 940 females against the 933 females in 2001. The rural (947 females in 2011 from 946 females in 2001) and urban (926 females in 2011 from 900 females in 2001) sex ratio also increased with minimizing the rural urban difference of 25 females from 2001 (46 females) to 2011 (21 females). In 2011, there have been recorded 879 females per 1000 males as contrasted to 861 in 2001 in total in the state. The rural and urban areas have also shown upward trend in 2011 then 2001 and registered a number of 882 and 873 females per 1000 males correspondingly.

The Fig. 1 clearly reflects that continuously, the sex ratio has remained against the women from 1901 to 2011 in both, country and state and slight difference in sex ratio in all groups prior to independence has been recognized with severe gender discrimination after independence. The high female mortality due to famine and outbreak of epidemics (plague and influenza) has been attributed to fall in sex ratio in decades of 1901 to 1921.

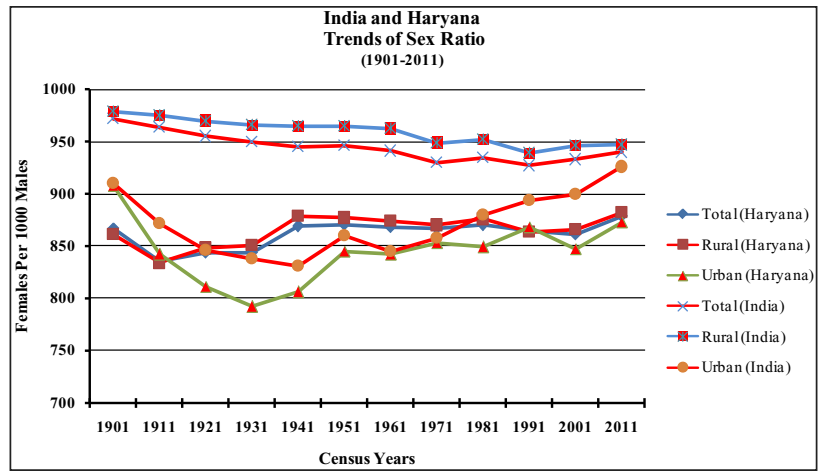

Fig. 1: Trends of Sex Ratio in Haryana and India

Further, the ignorance toward girl child, psychological and communal problems with women which later leads to high mortality in adolescent and high maternal mortality has been observed as major reasons behind continuous failing sex ratio. The pre-determination of sex and abortion following a prenatal diagnostic test is widely believed responsible contributors to this occurrence and incidences of honour killing in some socially backward areas also support this. In recent census the availability of better medical facilities, living conditions, more attention towards girls and social change have contributed to some improvement in sex ratio in the study area.

\section{Spatial Temporal Analysis of Sex Ratio in Haryana}

The state is not only having lowest sex ratio in 
the country but also observed incessantly fall in numbers of females per thousand males. The district wise profile shows that in 1981, the overall sex ratio was highest (939 females per thousand males) in Mahendergarh district against the state average of 870 females. The highest value has been followed by moderate in Rewari (925 females) and Ambala (902 females) districts whereas lowest proportion of females was recorded in Faridabad, Panchkula and Kaithal districts i.e. 812, 833 and 848 females (Table 2). In rural areas, district Mahendergarh again registered highest 947 number of females following by Rewari (931 females) and Bhiwani (908 females) districts whereas the lowest (842 females) is in Panipat district. In urban, districts Ambala and Faridabad have been listed as first and last with a sex ratio of 933 and 762 females per thousand males respectively.

In 1991, descend of five numbers (870 to 865 females) in sex ratio has been observed as compared to 1981 in the study area. There were 865 females in overall with 864 in rural and 868 in urban areas of the state in 1991. The district Rewari has come on first position in total (928 females) and rural (941 females) category while in rural class the district Panchkula has been traced with lowest number of females (830) per thousand males with Rohtak and Sonipat district having same number of 832 females. The districts Ambala and Mahendergarh districts have maintained their dominance in urban sex ratio with 950 and 901 females correspondingly and lowest possible sex ratio has been found in Faridabad (813 females) district.

In 2001 and 2011, some improvement has been noticed in sex ratio. In 2011, the overall sex ratio has been confirmed 879 females as contrasted to 861 in 2001. Overall, there was highest 918 females in Mahendergarh district in 2001. In rural, district Rewari recorded highest 910 females with a great decline of 31 numbers then previous census whereas

Table 2: Spatio-temporal pattern of Sex Ratio of Haryana

\begin{tabular}{|c|c|c|c|c|c|c|c|c|c|c|c|c|c|}
\hline \multirow[t]{2}{*}{ S1. No. } & \multirow[t]{2}{*}{ Districts } & \multicolumn{3}{|c|}{1981} & \multicolumn{3}{|c|}{1991} & \multicolumn{3}{|c|}{2001} & \multicolumn{3}{|c|}{2011} \\
\hline & & Total & Rural & Urban & Total & Rural & Urban & Total & Rural & Urban & Total & Rural & Urban \\
\hline 1 & Ambala & 902 & 883 & 933 & 903 & 879 & 950 & 868 & 879 & 849 & 885 & 892 & 876 \\
\hline 2 & Bhiwani & 897 & 908 & 849 & 878 & 879 & 875 & 879 & 884 & 859 & 886 & 886 & 885 \\
\hline 3 & Faridabad & 812 & 849 & 762 & 828 & 880 & 813 & 839 & 859 & 824 & 873 & 872 & 873 \\
\hline 4 & Fatheabad & 881 & 882 & 875 & 877 & 877 & 878 & 884 & 885 & 879 & 902 & 902 & 899 \\
\hline 5 & Gurgaon & 881 & 883 & 873 & 871 & 867 & 886 & 873 & 876 & 861 & 854 & 878 & 844 \\
\hline 6 & Hisar & 859 & 865 & 835 & 853 & 851 & 859 & 851 & 853 & 844 & 872 & 877 & 861 \\
\hline 7 & Jhajjar & 895 & 899 & 871 & 861 & 861 & 870 & 847 & 854 & 823 & 862 & 861 & 865 \\
\hline 8 & Jind & 856 & 856 & 858 & 838 & 834 & 859 & 852 & 851 & 857 & 871 & 868 & 881 \\
\hline 9 & Kaithal & 848 & 848 & 865 & 853 & 849 & 878 & 853 & 853 & 856 & 881 & 880 & 887 \\
\hline 10 & Karnal & 856 & 852 & 869 & 864 & 857 & 887 & 865 & 865 & 862 & 887 & 886 & 890 \\
\hline 11 & Kurukshetra & 872 & 877 & 855 & 879 & 883 & 867 & 866 & 873 & 848 & 888 & 899 & 862 \\
\hline 12 & Mahendergarh & 939 & 947 & 883 & 910 & 911 & 901 & 918 & 824 & 883 & 895 & 896 & 890 \\
\hline 13 & Mewat & DNA & DNA & DNA & DNA & DNA & DNA & DNA & DNA & DNA & 907 & 907 & 907 \\
\hline 14 & Panchkula & 833 & 846 & 793 & 839 & 830 & 852 & 823 & 798 & 853 & 873 & 863 & 881 \\
\hline 15 & Panipat & 850 & 842 & 867 & 852 & 850 & 871 & 829 & 837 & 819 & 864 & 860 & 868 \\
\hline 16 & Palwal & DNA & DNA & DNA & DNA & DNA & DNA & DNA & DNA & DNA & 880 & 880 & 883 \\
\hline 17 & Rewari & 925 & 931 & 883 & 928 & 941 & 859 & 899 & 910 & 851 & 898 & 907 & 873 \\
\hline 18 & Rohtak & 869 & 858 & 875 & 849 & 832 & 884 & 847 & 839 & 862 & 867 & 852 & 887 \\
\hline 19 & Sirsa & 878 & 888 & 841 & 885 & 887 & 876 & 882 & 884 & 876 & 897 & 898 & 896 \\
\hline 20 & Sonipat & 866 & 870 & 851 & 840 & 832 & 873 & 839 & 836 & 847 & 856 & 850 & 869 \\
\hline \multirow[t]{3}{*}{21} & Yamunanagar & 855 & 858 & 835 & 883 & 885 & 880 & 862 & 866 & 855 & 877 & 882 & 871 \\
\hline & Haryana & 870 & 876 & 849 & 865 & 864 & 868 & 861 & 866 & 847 & 879 & 882 & 873 \\
\hline & India & 935 & 952 & 880 & 926 & 938 & 894 & 933 & 946 & 900 & 940 & 947 & 926 \\
\hline
\end{tabular}

Source: Computed from PCA, Haryana 1981, 1991, 2001 and 2011. 
lowest sex ratio has been seen in Panchkula (798 females). Surprisingly Mahendergarh district turned to low category from top with great fall of 87 numbers in 2001 (824 females) than 1991 (911 females) in rural class whereas in urban the above said district has highest sex ratio (883 females) in the state and district Panipat is on bottom with 819 females per thousand males in 2001. During the census 2011, there was a little increase of 18 numbers in total sex ratio of the state and have been registered 879 females i.e. very low as compared to country's sex ratio of 940 females. In this decade, both in rural and urban sex ratio has raised and rolled 882 and 873 females per thousand males respectively (Table 2). The new emerged district Mewat with dominance of Muslim community scored first rank in all three categories (total, rural and urban) with same number of 907 females individually. In rural, the district Rewari has also highest 907 females equal to Mewat district. The district Sonipat has been placed very last with 850 females per thousand males in rural whereas Gurgaon district is in end with a figure of 844 females in urban class.

The numeral reveals that in 1981, seven districts namely Ambala, Fatehabad, Bhiwani, Jhajjar, Mahendergarh, Rewari and Gurgaon have listed in the category of high sex ratio in total followed by medium sex ratio in Kurukshetra, Sirsa, Rothak and Sonipat districts.

The low sex ratio has been observed in districts Panchkula, Yamunanagar, Kaithal, Jind, Hisar, Karnal, Panipat and Faridabad.

In case of urban area, the high sex ratio has been seen in the districts Ambala, Kaithal, Karnal, Panipat, Rohtak, Jhajjar, Fatehabad, Mahendergarh, Rewari and Gurgaon that is above 880 females per thousand males. The moderate sex ratio (860-880 females) is found in Yamunanagar, Kurukshetra, Jind, Sirsa, Hisar, Bhiwani and Sonipat districts associated by low sex ratio of Panchkula and Faridabad districts. The pattern of rural sex ratio resembles with total to some extent. The same districts with addition of Sirsa district have high sex ratio in total whereas in Hisar, Sonipat and Kurukshetra districts sex ratio is moderate.

The same districts of low category in overall lay also in low in rural category only replacement of Rohtak district with Hisar district. It has been found that comparatively northern and eastern parts of the state, western and southern Haryana the sex ratio is high in almost all three categories. It may be endorsed to the fact that because of social and economic backwardness, the people have no easy accessibility to pre-birth sex determination technology and abortion.

The figures exposes that in 1991, a cluster of five districts specially Ambala, Yamunanagar, Sirsa, Mahendergarh and Rewari recorded high sex ratio in total followed by moderate female deficiency in districts Kurukshetra, Karnal, Fatehabad, Bhiwani, Jhajjar and Gurgaon and low sex ratio in districts Kaithal, Jind, Hisar, Panipat, Sonipat, Rohtak and Faridabad.

The scene of urban and rural area is opposite with each other. In urban, Ambala, Karnal, Rohtak, Mahendergarh and Gurgaon districts has been put in high category of sex ratio whereas in rural this class is formed by Kurukshetra, Yamunanagar, Sirsa, Mahendergarh and Rewari districts. The eight (Kurukshetra, Yamunanagar, Kaithal, Fatehabad, Sirsa, Bhiwani, Jhajjar, Sonipat and Panipat) and five districts (Panchkula, Jind, Hisar, Rewari and Faridabad) have documented moderate and low sex ratio sequentially in urban class while in rural, Ambala, Fatehabad, Bhiwani, Jhajjar, Gurgaon and Faridabad district formulate the class of moderate sex ratio. The rest eight districts have low sex ratio in the state.

The observation reflects that almost all districts have improved their categories in 2011 as compared to 2001.

In total, only four districts (Sirsa, Fatehabad, Mahendergarh and Rewari) were in high sex ratio division in 2001 which have been supplemented by Mewat, Bhiwani, Ambala, Kurukshetra, Kaithal and Karnal districts in 2011. In the same way in urban, only in Mahendergarh district, the sex ratio was above 880 females in 2001 whereas in 2011, ten districts namely Ambala, Kurukshetra, Yamunanagar, Karnal, Sirsa, Fatehabad, Mahendergarh, Rewari, Mewat and Bhiwani cover the category of high sex ratio and only in three districts (Panchkula, Sonipat and Rohtak) the sex ratio has been found low in 2011 as compared to thirteen districts of 2001.

In rural, the four districts Fatehabad, Sirsa, Bhiwani and Rewari have recorded high sex ratio in 2001 
which have been increased by ten districts in 2011 with addition of Ambala, Yamunanagar, Kurukshtera, Karnal, Mahendergarh and Mewat districts. The moderate sex ratio has been seen in Kaithal, Jind, Hisar, Panipat, Jhajjar, Gurgaon, Palwal and Faridabad districts followed by low sex ratio merely in three districts i.e. Panchkula, Sonipat and Rohtak in 2011 as compared to ten districts of same category in 2001 census.

Surprisingly results show that socially and economically developed districts have low sex ratio as compared to rearward areas like Mewat. The reason behind it may be credited that there are less practice of family planning methods, female foeticide, abortion and pre-sex deciding in MeoMuslim dominant society due to the fear at the name of 'Allah or God' and didactic ignorance. The patriarchal structure of society, cultural rehearsal of demanding very expensive dowry from a girl's family and irresistible fear of sexual exploitation in surrounding milieu have been the major prevention for Indian families not wanting a girl child (Rustagi, 2006 and Myers, 2012).

Though the fact of coming more male population in industrially developed areas of the state for employment and other opportunities after lagging behind female in countryside excuses the imbalance in proportion of male and female population in urban, yet the educational height and attitude of society has significant impact on missing number of girls.

\section{CONCLUSION}

The above discussion is précised with results that during different survey poll, the state has witnessed not only the dearth of female population but also the rapidly declining rate. Though there is some augmenting in female proportion during census 2011 but it does not mean that the current situation is less shocking because in any category not a single district, as well as state, has recorded sex ratio more than national average. The range of differentiation on the basis of data rolled in 2011 varies from highest sex ratio of 907 females per 1000 males in district Mewat to lowest 854 females per 1000 males in Gurgaon district. The districts of western and southern part of the state which are less developed in terms of many health and education indexes have resulted superior sex ratio as compared to the northern and eastern districts that are not only facilitating highly industrialization and urbanization but also in cluster of high literacy rate and socially attentive. The rural and urban categories in all districts also have significant gap in sex ratio. On one side, in urban areas and educated society sexselective abortion is common and a number of girls' children are not allowed to be born while on another side, in rural areas, the murder of girls is frankly prevalent on the name dowry and fake honour that is normally known as 'honour killing'. So, it has been summarised that a balanced demographic structure in terms of sex composition in the state can be achieved only when women's will be empowered at assorted socio-economic and political arenas and every person of different social and cultural societies will have real and firm determination to stop discrimination between male and female child at their own home.

\section{Conflict of Interest - Nil}

Source of funding- Self by Authors

Ethical clearance- Nil

\section{REFERENCES}

Arnold, F., Kishor, S. and Roy, T.K. 2002. Sex Selective Abortions in India, Population and Development Review, 28(4): 759-785.

Atkins, P.J., Townsend, J.G., Raju, S. and Kumar, N. 1997. A Geography of Sex Ratio in India, Espace, Populations, Societies, 15(2): 161- 171.

Brogen, A.S., Shantibala, K., Rajkumari B. and Laishram 2009. Determination of Sex-ratio by Birth Order in an Urban Community in Manipur, Indian Journal of Public Health, 53(1): 7-13

Census of India. 1981. Primary Census Abstract, directors of Census Operations, Haryana.

Census of India. 1991. Primary Census Abstract, directors of Census Operations, Haryana.

Census of India. 2001. Primary Census Abstract, directors of Census Operations, Haryana.

Census of India. 2011. Primary Census Abstract, directors of Census Operations, Haryana.

Chhabra, A. 2011. A Woman Costs ₹ 30000, A Buffalo ₹ 70000..., An Article Published in India Today on May 9, 2011 and retrieved from indiatoday.intoday.in on December, 14th, 2016.

Chandna, R.C. 1996. Development and Population Growth: The Indian Experience, Population Geography, 18(1\&2): 9-26. 
Dasgupta, M. 1987. Selective Discrimination against Female Children in Rural Punjab, India, Population and Development Review, 13(1): 77-100.

Dawn, A. and Basu, R. 2015. Fluctuation of Sex Ratio in India with Special Reference to West Bengal, International Journal of Recent Scientific Research, 6(5): 3796-3801.

Edmeades, J. Pande R.P., Falle, T. and Krishan, S. 2011. Son Preference and Sterilization use Among Young Married Women In Two Slums In Bengaluru City, India, Global Public Health, 6(4): 407-420.

Jatrana, S. 2003. Explaining Gender Disparity in Child Health in Haryana State of India, Asian Meta Center for Population and Sustainable Development Analyses, Singapore, Research Paper Series, No. 16.

Kalantry, S. 2013. Sex Selection in the United States and India: A Contextualist Feminist Approach, UCLA Journal of International Law and Foreign Affairs, 61: 61-85.

National Institute of Public Corporation and Child Development. 2008. A Socio-cultural Study of the Declining Sex Ratio in Delhi and Haryana, A Report published by NIPCCD, New Delhi, pp. 3.

Majumdar, M. 2014. Almaring Sex Ratio and Problems of Female Foeticide and infanticide in India, Article accessed from website lawquestioninternational.com on December $15^{\text {th }}, 2016$.
Myers, C. 2012. Sex Selective Abortion in India, Global Tides, 6(3): 1-18.

Rustagi, P. 2006. The Deprived, Discriminated \& Damned Girl Child: Story of Declining Child Sex Ratios in India, A revised version of a paper presented at the writer's workshop on 'The Wellbeing of India's Population: A Compendium of Selected Perspectives' held in New Delhi: 6-7.

Sharma, M., Kumar, S. and Kavita 2018. Disappearing of Daughters or Failure to Perforate the Chakravyuha of Favoritism from Womb to tomb. Medico-Legal Update, 18(2): 211-218.

Sharma, M. and Kumar, S. 2018. Regional Dimensions of Health Status of Children in Haryana. Indian Journal of Public Health Research and Development, 9(11): 82-87.

Singh, H.K. 2010. Gender Imbalance in Socio-economic and Demographic Characteristics: 2001 Census, Orissa Review, Census Special, pp. 223.

Stoller, R.J. 1968. Sex and Gender: On the Development of Masculinity and Femininity, Published by New York: Science House.

United Nation Organization. 2014. Sex Ratios and Gender Biased Sex Selection History, Debates and Future Directions, Published by UN Women Multi-Country Office for India, Bhutan, Maldives \& Sri Lanka, New Delhi, pp. 8. 
